\title{
Financial Inclusion in Ethiopia
}

\author{
Andualem Ufo Baza ${ }^{1} \&$ K. Sambasiva Rao ${ }^{1}$ \\ ${ }^{1}$ Department of Commerce \& Management Studies, Andhra University, Visakhapatnam, India \\ Correspondence: Andualem Ufo Baza, Department of Commerce \& Management Studies, Andhra University, \\ Visakhapatnam, ON, MVP R-15, India. Tel: 9-553-152-392. E-mail: bazzafin.au@ gmail.com
}

Received: February 12, 2017

Accepted: March 20, 2017

Online Published: March 25, 2017

doi:10.5539/ijef.v9n4p191

URL: https://doi.org/10.5539/ijef.v9n4p191

\begin{abstract}
This paper analyzes the demand and supply side data to show the status of financial inclusion in Ethiopia. Using a set of survey instruments on demand side and data on supply side of financial inclusion, we first analyzed the demand side survey on account, saving, credit, payment, insurance and financial resilience as well as barriers to financial inclusion. Then, we determined and analyzed the supply side of the financial inclusion such as trends in the number of deposit accounts and loan accounts, branch per capita, branch density, ATMs per capita and ATMs density and the retail payment instruments penetration. The analysis of supply side study covered the data for the period from 2006 to 2015. We find that in Ethiopia 33.86 percent of adults has an account at formal financial institution in the year 2016. They use their account to keep money safe, send and receive payments, and to get credit services and foreign exchange services. Using the data on the supply side of financial inclusion in Ethiopia as of December 2015, we find that the branch per capita and branch density of 5.54 and 3.09 respectively. We find that barriers to financial inclusion such as lack of money, distance, fixed cost, and documentations are important obstacles in Ethiopia.
\end{abstract}

Keywords: financial inclusion in Ethiopia, demand side, supply side, Ethiopia

\section{Introduction}

The assertion that financial inclusion is the mere opening of account at formal financial institution can be refuted. Probably this mere belief may be based on the fact that the opening account does not change the live of households. But it is not always true and it does not stop there only with regular use people can fully benefit from having an account. Aportela (1999) describes having bank account increases savings. His study mentioned access to financial service increases saving rate at least between 3 and 5 percentage points. It is possible that having financial account or simple saving product can empower women in household decision making process Ashraf, Karlan, and Yin (2010). Dupas and Robinson (2009) describe having an account or simple commitment savings can smooth consumption and finance productive investment of entrepreneurs. Several studies have found that having formal account for individuals as well as firms has several benefits. Demirguc-Kunt, Klapper, Singer, and Oudheusden (2015) also mentioned having an account as well as access to saving and payment methods can increase savings, empowers women, and boosts productive investment and smooth consumption. The studies conducted by Karlan and Zinman (2010) finds that access to credit has substantial positive impact on smoothing consumption as well as employment and income and some aspect of mental health and outlook.

A related finding by Beck, Levine, and Levkov (2010) shows that greater financial inclusion accelerates economic growth, intensifies competition, and boosts the demand for labor. Those individuals at the lower end of income distribution can get relatively bigger benefit and hence inclusive growth can be achieved. Same studies find that increased access to well suited savings and payment products can enhance reduce extreme poverty and boost shared prosperity. Financial inclusion refers to the process of promoting affordable, timely and adequate access to a wide range of regulated financial products and services and broadening their use by all segments of society through implementation of tailored existing and innovative approaches including financial awareness and education with a view to promote financial well being as well as economic and social inclusion (OECD, 2013). Financial exclusion is a great part of social exclusion and needs the government action. Ethiopia is a developing nation with majority of unbanked population. Therefore, studying about financial inclusion is relevant for Ethiopian development agenda.

This study identified that Ethiopian financial sector consists of 19 banks with 3,093 branches, 35 microfinance 
institutions with 1,593 branches (721main and 872sub branches), 17insurance companies with 377 branches and 5 Capital Goods lease companies (operated through five core microfinance institutions in the jurisdiction) (as of December 2015).

Although Ethiopia has reformed its financial sector in the last couple of decades, the financial sector still remains immature, even relative to the averages of Sub-Saharan African economies and many other low income economies found in various regions of the world. An indicator for this is there is large gap in financial inclusion, the share of adults of age greater than 15 years who have an account at financial institution or mobile money account is 22.79 percent and almost Opercent respectively, in 2014 (World Bank, 2014a). In average in the Sub-Saharan Africa countries these number are 28.9 percent and 11.5 percent respectively, in 2014. In low income countries the number are 22.3percent and 10 percent respectively, in 2014 (World Bank, 2014a). Ethiopia lags significantly behind the other Sub-Saharan African countries in all measures of financial access, including number of bank branches and ATMs per 100,000 adults as well as depositors and creditors per 1000 adults were 1.3; 0.241; 136.13; and 2.09 respectively, in 2012 (IMF, 2014). While the data on all these indicators of Sub-Saharan Africa were above all these indicators of Ethiopia. The limited reach of the financial sector constrains the opportunities for young firms and savings products for the poor, subjecting them to vulnerabilities in the event of shocks. The structure and regulation of Ethiopia's financial system contribute to these limitations (IMF, 2013). The heavily directed lending to public enterprises mainly by commercial banks of Ethiopia became a stumbling block for this credit inclusion. In addition to reach of financial sectors, bureaucratic and financial obstacles also challenge individuals and firms from accessing and using financial services in Ethiopia. The above-mentioned problems in the financial system of the Ethiopia is partly attributable to the low level of branch outreach, the limited saving products for the poor and low access to finance, especially for credit services. Financial inclusion is critical for economic growth (World Bank, 2014a). For instance, existing studies argues financial inclusion as a key tool for economic growth and poverty reduction (see, e.g., Demirguc-Kunt et al., 2015). Given that having bank account is one of the most essential forms of financial inclusion, one would expect that having bank account enhances saving (Aportela, 1999), empower women in decision making (Ashraf, Karlan, \& Yin, 2010), smooth consumption and finance productive investment (Dupas \& Robinson, 2009; see also, Demirguc-Kunt, Klapper, Singer, \& Oudheusden, 2015). The access to credit can smooth consumption, employment, income and good mental position (Karlan \& Zinman, 2010). In this context, it is worth researching the possibilities of identifying and addressing barriers in the financial inclusion as well as financial inclusion status and, thereby, enhancing the inclusive financial system for reducing poverty and achieving inclusive economic growth.

This study seeks to answer controversial questions about competing stories regarding financial inclusion in Ethiopia. These are: (1) why do some people own accounts and others excluded? How many Ethiopians are financially excluded and why? (2) Why do some use their accounts; to save formally, to make and receive payments and others not? How many people or firms in Ethiopia did own account and use financial services? (3) Where is the source of financial resilience for individuals at the time of emergency? (4) What did the trends of deposit accounts and credit accouts look like? Some look deeper into; what are the barriers to inclusion? What produces the barriers to financial inclusion that make obstacles to promote inclusion? Why financial inclusion matters? Is financial exclusion a problem for Ethiopians? Who are financially excluded? Where do the financially excluded Ethiopians reside? And other controversial research questions on financial inclusion were raised to comprehensively put the status of financial inclusion in Ethiopia. Our data and analysis advances thinking about these controversial issues of financial inclusion and barriers to inclusion. The main objective of this study is threefold. The first goal is to measure the access to financial services in Ethiopia. The Second goal is to measure the usage of financial services in Ethiopia. The third goal is to identify and address barriers to financial inclusion in Ethiopia. The final goal is to analyze and document the significance of access to and usage of financial services in financial inclusion policy decision making. Section 2 reviews the literature. Section 3 describes our research methodology. Section 4 presents the results of our analysis. Section 5 concludes and recommends.

\section{Literature Review}

Financial inclusion refers to ensuring access to tailored financial products and services needed by low income individuals in particular and society in general at fair, transparent and equitable mode. The financial inclusion in most simple term is having an account at financial institutions. The financial institution could be bank, microfinance institutions or other regulated financial institution. Access to financial services can be achieved through offering appropriate financial products for low income individuals in particular and society in general. The tailored saving products as well as saving institute expansion can enhance saving of low income people. The 
credit inclusion can be enhanced through designing appropriate products, credit information and low collateral requirements.

For a sample of 150,000 people in 143 countries in 2014, Demirguc-kunt, Klapper, Singer, and Oudheusden (2015) find that financial inclusion through technological innovation particularly mobile money, enhance to rapidly expand the financial services in Sub-Saharan Africa. In this case digitalizing payments can make payments easier, more affordable and better secure.

The technological innovation reduces financial exclusion by reducing the distance, cost barriers and transaction insecurity. It increases the access to financial services.

Expansion of saving institute can tend to increase the savings of low income individuals. Access to financial service and instruments increases saving rate at least between 3 and 5 percentage points (Aportela, 1999). Access to simple saving account can empower women in household decision making, as mentioned by (Ashraf, Karlan, \& Yin, 2010). In general, savings can smooth consumption enhance productive asset ownership (Dupas \& Robinson, 2009). Saving can be a source for emergency fund (World Bank, 2014a; Demirguc-Kunt, Klapper, Singer, \& Oudheusden, 2015).

Empirical researches has looked at access to credit which can smooth consumption, enhance employment and income as well as promote healthy living (Karlan \& Zinman, 2010) conducted an experimental of consumer credit access to borrowers at 200 percent Annual Percentage Rate and find that randomly assigned additional credit produced significant amount of net profit for borrowers across a wide deviation of outcomes.

The individuals and firms that are financially included can benefit the most from saving, credit and payment services provided by the financial institutions. In particular, access to cheaper credit allows individuals to smooth their consumption.

For sample of studies conducted in China more generally, Cai and others (2010) find that, access to formal insurance increases propensity of farmers to raise sow in china. Beck, Levine, and Levkov (2010) study shows that greater financial inclusion accelerates economic growth, intensifies competition, and boosts the demand for labor. Those individuals at the lower end of income distribution can get relatively bigger benefit and hence inclusive growth can be achieved.

\section{Research Methodology}

In this section we discuss the methodology applied for comprehensive financial inclusion studies in Ethiopia. To achieve the main objectives of the study we have designed the suitable methodology. Below, we explain the methodology and data that we collect and use in our analysis.

\subsection{Measures of Access to and Usage of Financial Services}

In this study, we employ the measure of access to and usage of financial services that are categorized into two. These are measures of access to financial services that has eight indicators: (1) number of branches per 100,000 adults (2) number of ATMs per 100,000 adults (3) number of agents of payment service providers per 100,000 adults (4) number of prepaid cards per 100,000 adults (5) number of POS terminals per 100,000 adults (6) percentage of adults with access to mobile phone or devices or internet access in home (7) number of debit cards per 1000 adults (8) interoperability of ATMs. The Usage of financial services has eight indicators and four sub-indicators these are: (1) percentage of adults who reported having an account at formal financial institution either by their own or together with other person (2) deposit accounts per 1000 adults (3) number of mobile money transactions per 100,000 adults (4) percentage of adults with at least one loan outstanding from bank or other financial institution (5) outstanding loan per 1000 adults (6) Percentage of adults using transaction account with formal financial institution to make or receive digital payment (6.1) sub-indicator: percentage of adults using a mobile phone to pay bills, make purchases, send or receive money from an account at formal financial institutions (6.2) sub-indicator: percentage of adults using the internet to pay bills, make purchases, send money online (6.3) sub-indicator: percentage of adults using debit card to directly make payment from an account at formal financial institution (6.4) sub-indicator: percentage of adults who received wages or government transfers into an account with formal financial institution (7) percentage of adults with high frequency use of accounts (8) percentage of adults that saved at bank or other financial institution in the past year. We used the existing most relevant and latest parameters and measures to better indicate the overall aspect of financial inclusion of the jurisdiction. All data related to access and usage of financial services are collected through survey of demand side, which was conducted by the researcher in 2016 with 340 randomly selected adults from 34kebele in Ethiopia using multi-stage cluster sampling and the supply side data collected from the National Bank of Ethiopia and other institutions (CSA, MOFEC and NPC) in Ethiopia. We used the demand side survey and 
supply side data and survey and dentified barriers to financial inclusion.

\section{Results}

\subsection{Access to and Usage of Financial Services by Individuals}

Access to financial services has recently become like a part of fundamental right of people in the jurisdictions, as financial exclusion is decried as discriminatory and a broad set of social exclusion if it is identified as involuntary exclusion, discrimination or exclusion based on sex, tribe or other related criteria. Until today, we know little about financial exclusion in Ethiopia; those adults excluded from having formal financial accounts and mobile money accounts as well as whom they are (are they women, poor, rural residents, migrants, low-income people) and extent of their exclusion. Using demand side survey and supply side data, we analyzed. We find evidence that in Ethiopia, in 2016, about 36.5million adults (66.14 percent adults) are unbanked, without an account. The evidence shows that the reason for such exclusion is lack of money, distance, documentation requirements are important barriers to financial inclusion. The evidence indicates the structure and regulation of financial system is main obstacle to credit exclusion. We identified low product diversification or market failure is reason for deposit exclusion of low-income individuals that demands the saving products.

\subsubsection{Accounts Penetration}

We find that in Ethiopia, 33.86percent of adults have account at formal financial institution. The evidence shows that they use their account to keep money safe, send and receive payments (such as salary, remittance and government benefits), and to get credit services and foreign exchange services. We find in jurisdiction only 0.028 percent adults reported having a mobile money account, in 2016 (Figure 1).

When we compare the alteration in ownership of account over time, between 2016 and 2014, the share of adults with a financial account increased by 12.06 percentage points, from 21.8 percent in 2014 to 33.86 percent in 2016 (Figure 1). And we find that the number of adults without a financial account the unbanked decreased from 42.15 million to 36.5 million. However, the number of unbanked adults decreased by 5.65 million, the number of adults who became account holders over this period is in reality more than 6.9 million. The variation between these numbers is due to growth in adult population. In 2014 the Ethiopian adult population was 53.9 million, with 11.75 million adults having a financial account and 42.15 million being unbanked. Whereas by 2016 the adult population in Ethiopia was 55.19 million, with 18.69 million adults having a financial account and 36.5 million unbanked.

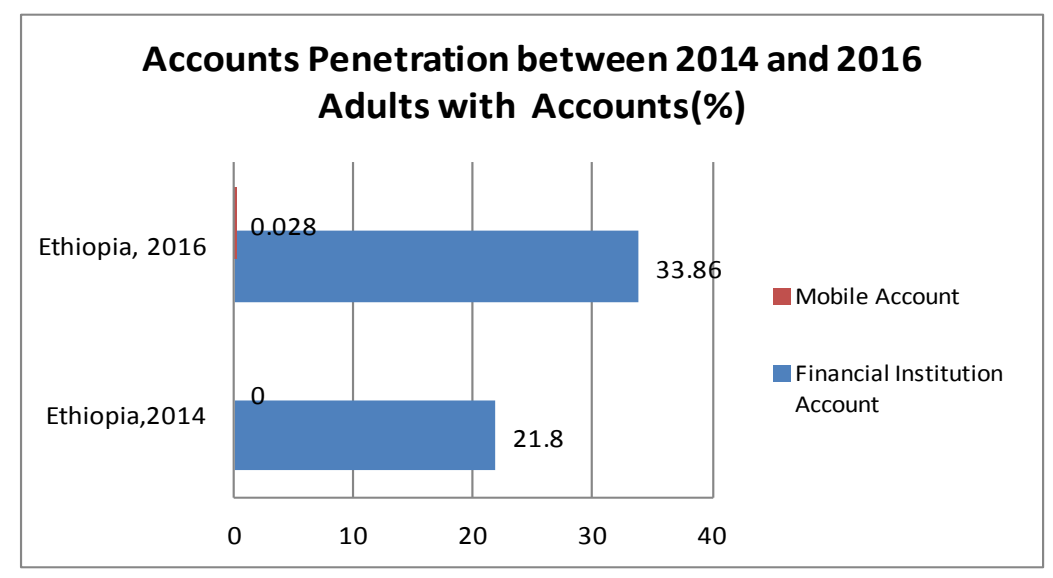

Figure 1. Accounts penetration overtime in Ethiopia

Source: Author's analysis of Survey, 2016 and Global Findex database, 2014.

We show the evidence that main the reason for robust growth in financial institution account penetration appears to be the expansion of commercial bank branches from 2,208 (as of June 2014) to 3,093 (by December 2015). Whereas, the share of adults with mobile money account has increased with overall penetration of 0.028 percent, but it is not satisfactory growth while strong potential of adults with a mobile phone or access to internet of more than 57 percent in the jurisdiction. In Ethiopia mobile money services is offered by two newly established providers:hello-cash and M-Birr. 
In the jurisdiction ownership of account differ by personal characteristics such as income, gender, age, and geography (rural-urban residence). In Ethiopia adults in the poorest 40 percent of households in which 15.9 percent are having a financial account and those in the richest 60 percent 25.7 percent having a financial account the data shows a gap of 9.8 percentage points in account penetration between the two groups. We find that in jurisdiction, 35.15 percent of men reported having a financial account in 2016, while only 32.63 percent of women did. The evidence shows gender gap of 2.52 percentage points. By the year 2014 the gender gap was 1.62 percentage points. This evidence shows the gender gap is small, but persistent over time. In Ethiopia, young adults (ages 15-34) are less likely than older adults (age 35 and above) to have an account. We find that in 2016, young adults (ages 15-34) having a financial account are 30.05 percent whereas, the older adults (age 35 and above) having a financial account are 39.45 percent. While the gap in account penetration between these two ages groups in 2016 is 9.40 percentage points. By the year 2014 the youth gap was 6.05 percentage points. This evidence shows the youth gap is persistent over time. In Ethiopia the unbanked live predominantly in rural areas. In jurisdiction 42.6 million adults live in rural area, while 12.59 million only live in urban areas and rural areas are out of availability of financial services, infrastructures and institution. We find that in 2016, 28.07 percent of rural residents have an account. By the year 2014 the rural residents having an account is 18.7 percent. These show that there is continuous change in account ownership of 9.37 percentage points (see Global Findex database for 2014 data).

\subsubsection{Barriers to Financial Inclusion}

\subsubsection{Survey Results on Barriers to Financial Inclusion}

In Ethiopia, in 2016, 61 percent of adults did not have any account. They cited the lack of money to use a bank account as a reason, and 25 percent reported it as the only reason. We find evidence that in Ethiopia the main barriers to bank account use are lack of money, distance, cost, documentation and other barriers like another family member already has an account, lack of trust and religious reasons are reported in their decreasing order of frequency (Figure 2).

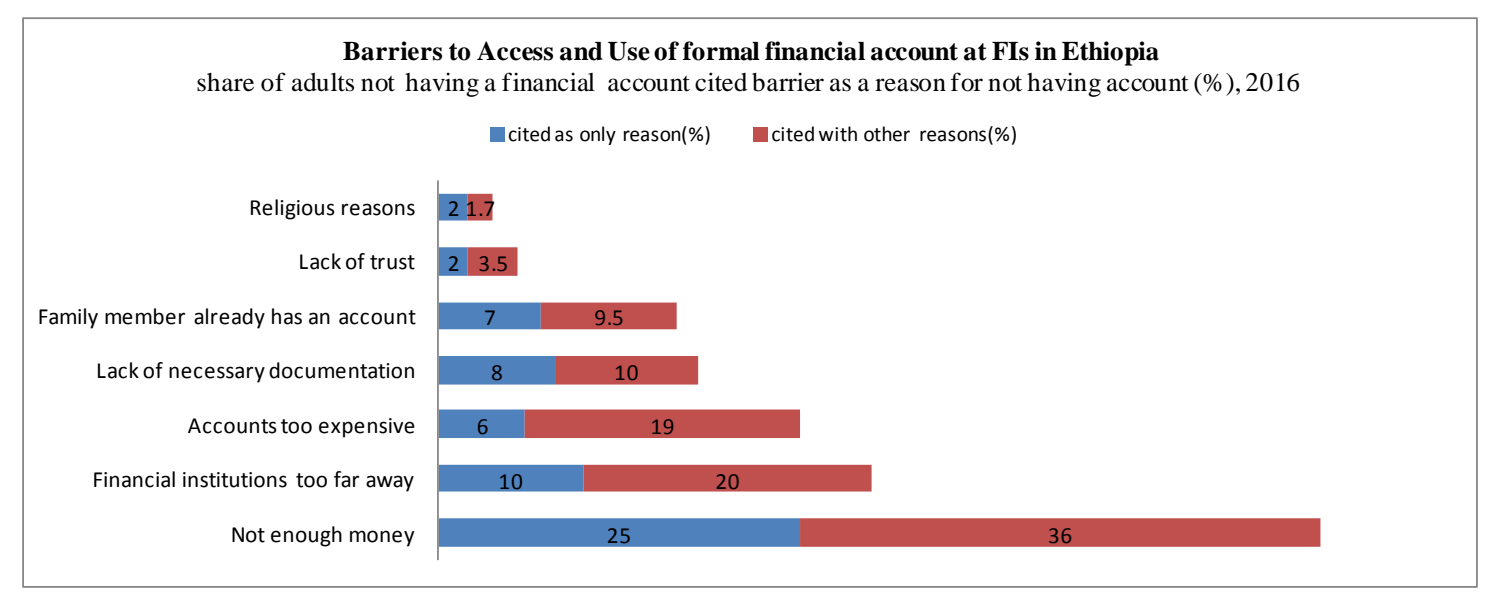

Figure 2. Barriers to financial inclusion in Ethiopia (\% adults)

Source: Author's analysis of Survey, 2016.

We find evidence that people should travel an average of $19 \mathrm{~km}$ to access a bank branch or ATMs. The evidence shows the average cost incurred is Birr 12 and 90minutes average walking time. The opening cost of saving account with exception of commercial bank of Ethiopia ranges from Birr 25 and Birr 50. Opening cost of checking account is Birr 1,000. The over-the counter money transfer is Birr 23 up to transfer of Birr 4,000 and increasing with increase in amount. These fixed costs of intermediation prohibit the low-income individuals and the poor from owning an account. We find evidence that getting credit is very difficult for low-income individuals, because it needs collateral of more than 150 percent of amount of credit requested and connections as well as state bank directed lending to public organizations excludes individuals from credit market participation. We have evidence that getting credit is based on connection and amount of income level, richest appears to get it than the poorest.

We asked questions to the National Bank of Ethiopia employees and the survey report found that physical, 
bureaucratic and financial barriers are the important obstacles for expanding financial inclusion in Ethiopia. The financial institutions structure and regulation is found to be the barrier for credit in Ethiopia for both individuals and small and medium enterprises. In general, market failure appears to be the essential obstacle in this aspect and the poor are very constrained to get formal saving products which leads to increase in informal saving in jurisdiction.

\subsubsection{Usage of Formal Accounts}

We find that in Ethiopia in 2016, 45.8 percent of adults with a financial account at formal financial institution reported making one to two times deposit and 16.83 percent one to two times withdrawal in a typical month. We show evidence that 2016, 85 percent of adults with a financial institution account reported normally using a bank teller to withdraw cash, and only 2.17 percentage of adults use ATMs as a mode. Use of ATM machine for withdrawal of money is slowly changing overtime between 2016 and 2014, as the share of adults grow at 1.27percentage points, but using bank teller increase by 2.1 percent (see Global Findex database for 2014 data).

\subsubsection{Savings}

We find evidence that in Ethiopia, in 2016, 22.37 percent of adults reported having saved formally in the past 12 months, at financial institution such as bank or microfinance institution. While 36.9 percent of adults saved semiformally in the past 12 months. The evidence shows that in the jurisdiction, 51.2 percent of adults saved both formal and semiformal in the past 12 months. In Ethiopia formal financial institution that accepts deposit are commercial banks and Microfinance institutions. The informal saving is saving with rotating savings and credit association (ROSCA) or using an informal savings club or a person outside the family like iddir and Iqube or saving money at home "under the mattress" or saving in the form of jewelry, livestock, or other real asset. We find that there is a change in saving behaviour overtime. When we compare the saving behaviour over time, in jurisdiction 22.37 and 13.63 percent of account holders in 2016 and 2014 respectively reported having saved formally (Figure 3, below).

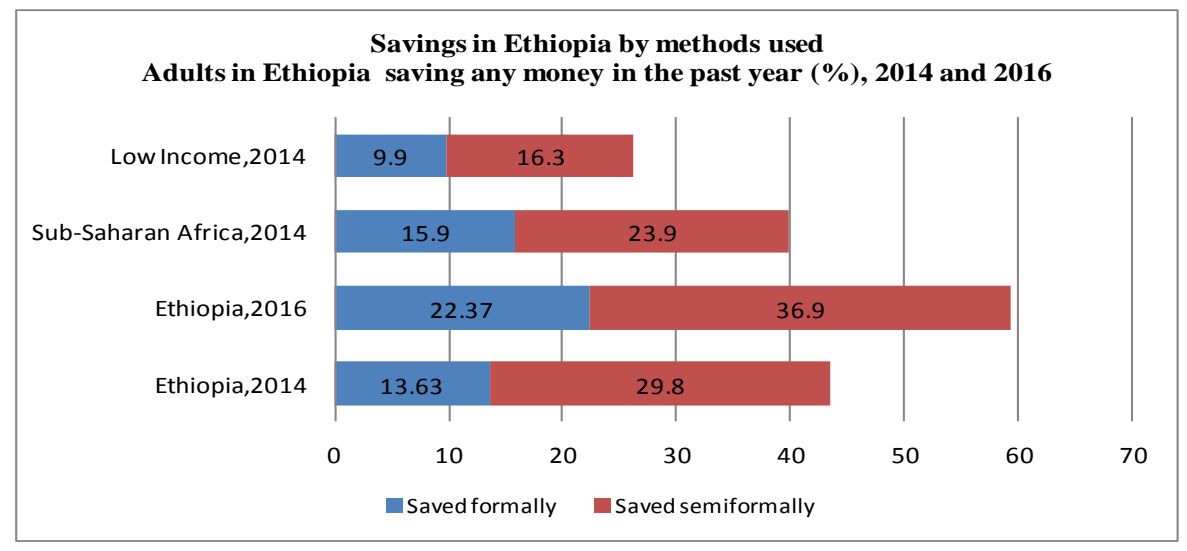

Figure 3. Saving in Ethiopia

Source: Author's analysis of survey 2016 and Global Findex database updated 08/2015.

These analyse shows that share of adults who reported having saved at formal financial institution in the past 12 months increased by 8.74 percentage points. On the same period, in jurisdiction the share of adults who reported saving semiformally, by using an informal savings club or a person outside the family, 29.8 and 36.9 percent in 2014 and 2016 respectively. This shows that there is increase in informal saving by 7.1 percentage points. We find that in jurisdiction, in 2016, about 9.71 percent of adults reported having saved in the past year for old age, 8.8 percent for education or school fee, and 18.53 percent to start, operate or expand business or farm.

\subsubsection{Credit}

We find evidence that in Ethiopia, in 2016, 47.3 percent of adults reported having borrowed money in the past 12 months (Figure 4). 


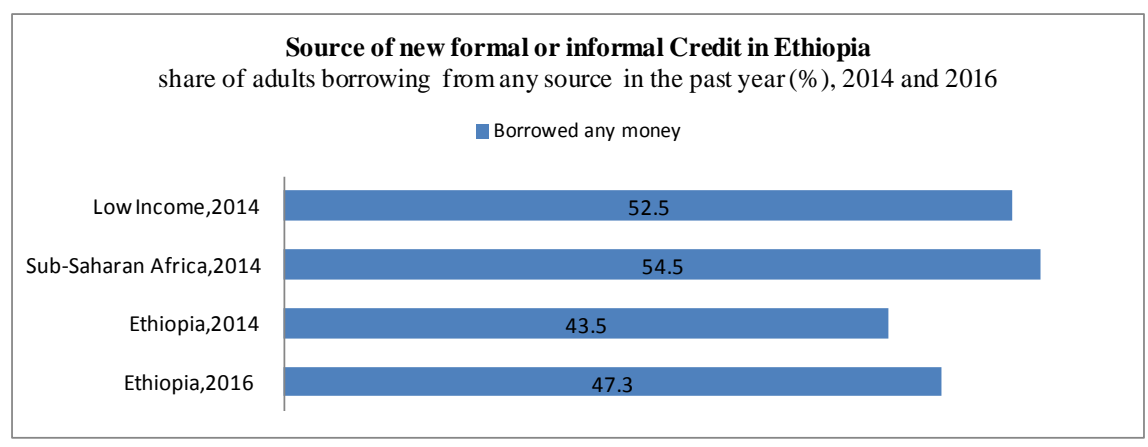

Figure 4. Credit in Ethiopia

Source: Author's analysis of survey 2016 and Global Findex database updated 08/2015.

We find evidence that in jurisdiction, in 2016, family or friends was the most frequently reported source of new loans, with 33.8 percent of adults reporting they had borrowed in past 12 months. While in the same year adults who reported store credit, financial institutions and private informal lenders were the source of their new loans 11, 8.7 and 1.17 percent respectively, reporting that they had borrowed. We have evidence that the borrowing trend changed over time. In jurisdiction, in 2016 and 2014 the share of adults who borrowed from a financial institution were 8.7 and 7.4 percent respectively. These show that there was an increase by 1.3 percentage point between 2016 and 2014. We find that in 2016, 11.47 percent of adults reported having borrowed for health or medical purposes in the past 12 months. While 4.68 and 14.8 percent of adults reported having borrowed for education and to start, operate and expand business respectively, in the past 12 months. We find that in 2016, 18.53 and 14.8 percent of adults reported having saved and borrowed in the past 12 months to start, operate, or expand a business or farm respectively.

\subsubsection{Payments}

We find that in Ethiopia, in 2016, 1.08 percent of adults reported having used an account in financial institutions to receive wage payments. In jurisdiction about 6.47 percent reported receiving their wages in cash only, in 2016. And the other 2.05 percent reported receiving their wages or salary in the past 12 months directly using ATM, bank transfer or check. We find that about 97.52 percent of adults reported getting payments for the sale of their parent's agricultural goods in cash in the past 12 months, in 2016. We find evidence that, about 97.49 percent of adults reported having made regular payments for water, electricity, or trash collection in cash in the past 12 months. This shows that making payment for utility in cash is a predominant mode in Ethiopia. We find that School fees is dominantly in cash, in 2016 those who made regular payment for school fee is 94.37 percent in the past 12 months. In 2016, the domestic remittances are about 12.97 and 14.87 percent of adults reported having received and sent respectively. We find that domestic remittances are mainly sent from children or relatives working in other parts of Ethiopia (domestic migrants for work) to family and received from family for purposes of education, work or with other purposes. Therefore, the digital method of payment matters for advancement of financial inclusion. The digital method of payments such as mobile banking, mobile money can make it faster, easier and cheaper. They have advantage of both transaction security and economic security.

\subsubsection{Insurance}

We find that in 2016, in Ethiopia, 2.65 percent of adults reported having motor/vehicle insurance in the past 12 months. While only 0.88 percent of adults reported having medical or health insurance. Nonetheless, microinsurance in Ethiopia, especially weather index-insurance is at pilot stage and only slightly implemented in Borena zone of Oromia region. Overall, in Ethiopia 3.53percent of adults reported having insurance (National bank of Ethiopia supply side survey).

\subsubsection{Financial Resilience}

In the 2016 survey adults were asked to respond as to how possible it could be for them to come up with money in the case of an emergency. We have given the choice, very possible, somewhat possible, not very possible, or not at all possible to come up with an amount equivalent to Birr 510 or 1/20 of Ethiopia gross national income per capita within the next month. We asked too, to respond for the main source of such funding. We find that 70.9 percent of adults reported that it could be possible to come up with this amount, while 29.1 percent reported that it would be not be at all possible, in 2016. We find that, 42.3 percent of adults reported their main source of funds are family and friends, in 2016 . While 29 percent reported employer loan as their main source, followed by 
14.8 percent reporting other sources, and 12.1 percent reporting saving, in 2016 (Figure 5). (See GNI figure on world Development Indicators).

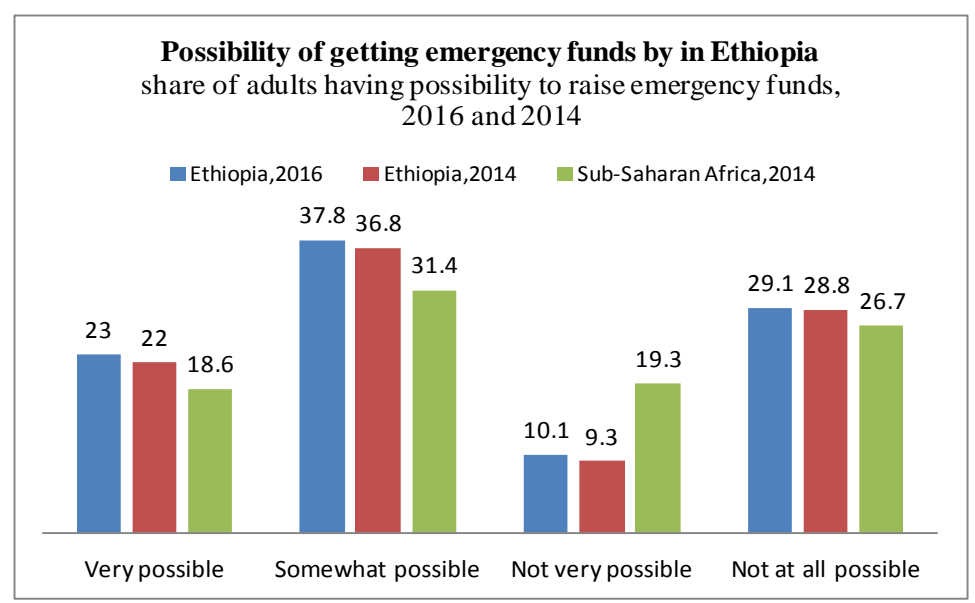

Figure 5. Possibility of getting emergency funds by adults in Ethiopia

Source: Author's analysis of survey 2016 and Global Findex database updated 08/2015.

\subsubsection{Financial Inclusion of Firms}

In Ethiopia firms own account at formal financial institution were 92 percent in 2015/16. By 2011, the percent of firms own financial account were 94 percent. As we compare the percent of firms owned account between 2011 and 2015, it shows a decline by 2 percentage points (Figure 6). This decline between the periods appears to be increase informal firms that do not have formal accounts or exit of existing firms for unreported purpose.

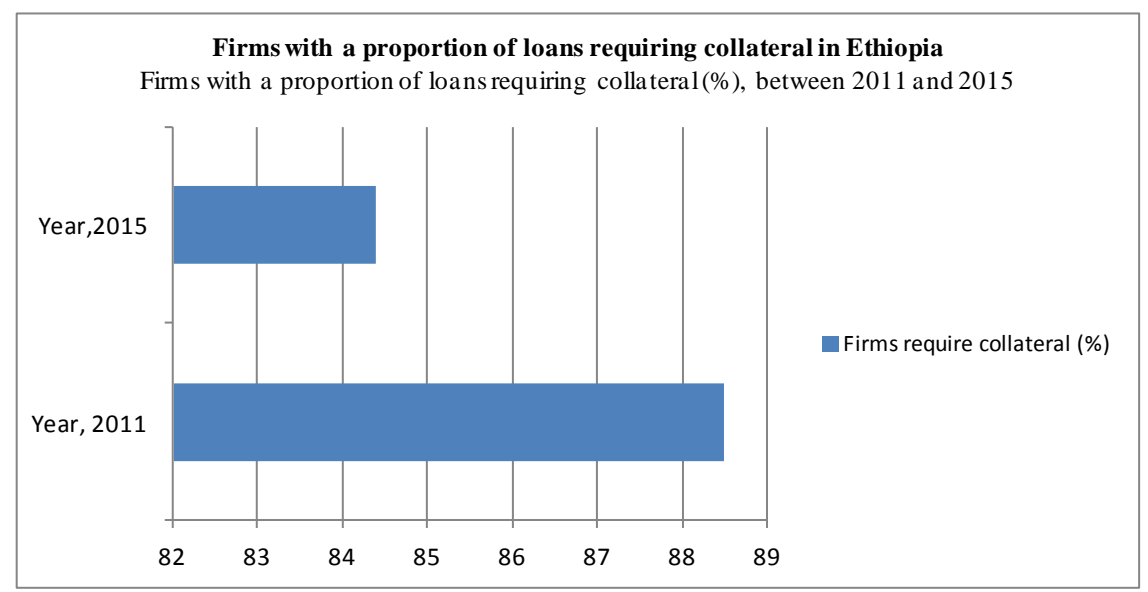

Figure 6. Firms with an account at formal institution in Ethiopia

Source: Global Findex Database updated 08/2015.

The firms with an outstanding loan or line of credit are 29.6 percent in 2015/16. This shows that 70.4 percent of firms in Ethiopia tend to be no line of credit from financial institutions. The evidence shows there were huge constraint of credit line for business firms in jurisdiction. While the firms with a proportion of loans requiring collateral are 84.4 percent in 2015/16. In other words, this means only 13.6 percent of business firms financed by credit without collateral. Further, this evidence shows 84.4 percent of business requires collateral asset that should be pledged for loan they want to get from financial institutions. This analysis indicates poor and small firms become excluded from credit market due to this limitation. Hence, it leads for credit exclusion. The evidence shows that firms with at least one female owner with an account at a formal financial institution were 92.5 percent in 2015/16. In other words, this evidence show 7.5 percent of female firm owners do not have an account at formal financial institution. The firms with at least one female owner with a proportion of loans 
requiring collateral were 70.5 percent in 2015/16. On contrary, this means only 29.5 percent of female owned firms do not need to provide collateral for loan. The firms with at least one female owner with an outstanding loans or line of credit are 36.7 percent in 2015/16. By 2011, the percent of firms with at least one female owner with an outstanding loans or line of credit was 11.7 percent. As we compare the percent of firms with at least one female owner with an outstanding loans or line of credit between 2011 and 2015 the percentage shows a declining trend by 25.1 percentage points. In jurisdiction, in 2016, the firms who reported access to finance as their main obstacle are 40.4 percent (see enterprise survey database).

\subsubsection{Analysis of Financial Inclusion}

Analysis of provider's side data of financial inclusion indicates the use of financial services in Ethiopia is unevenly distributed and it depends on higher population density and greater proximity to access points; densely populated few urban areas have higher density of bank branches, ATMs, agents and POS terminals and has greater use of financial services than rural areas. We show evidence that 3,093 bank branches in Ethiopia (as of December 2015) out of which 1,094 bank branches (35.35 percent) are concentrated in single capital city, Addis Ababa with a population size of only 3 million. The remaining bank branches are attributable to the entire 87 million populations (estimated 53.8 million adults). The evidence shows that ATMs used for withdrawal of cash only709 (as of December 2015) and POS terminals 1,635 (as of December 2015). The number of merchants and debit cards are 1,214 and 860, 463 respectively (as of December 2015). The number of prepaid cards and number of bank agent (correspondent banking) are 520 and 631 respectively (as of December 2015). In Ethiopia, in 2016, the number of mobile money transactions per 100,000 adults was only 0.24percent. In Ethiopia, in 2016, (24,752 transactions transfer/payment were made via mobile) with a 0.028 percent shares of people having mobile money account. In the period only (2, 024 and 10, 542 transactions, transfer/payment made via Internet; and transfer/payment made via Agent with transaction value in Birr 54,611,080 and 6,538,280 respectively, in 2016). This shows that electronic payment penetration is very low in Ethiopia. We analyzed the branch penetration in Ethiopia by both demographic and geographic penetration. We find that branch per capita in Ethiopia is 5.54(as of December 2015). The branch density is 3.09 (as of December 2015).

We analyzed the ATMs penetration in Ethiopia by both demographic and geographic penetration. We find that ATMs per capita in Ethiopia is 1.28 (as of December 2015). The ATMs density is 0.709(as of December 2015). The percentage of Ethiopians having ATM cards is 1.56 percents (as of December 2015). The evidence shows that interoperability of ATMs is fully implemented and interoperability of POSs terminals also commenced in the jurisdiction. We analyzed both deposit and credit penetration in Ethiopia. we find that the deposit penetration and credit penetration proxied by number of depositors account per 1,000 adults and number of creditors account per 1,000 adults shows that 334.8 and 3.36 respectively (as of December 2015).
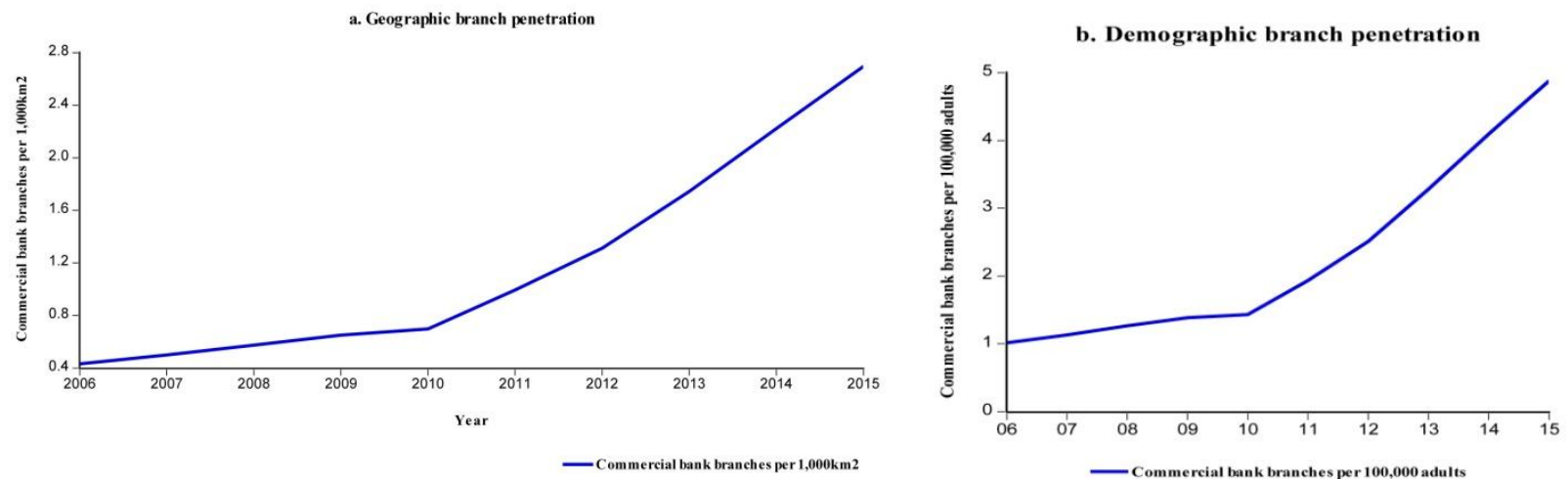

Figure 7. Branch penetration: Geographic and demographic branch penetration

Note. Number of Commercial bank branches bank branches per 1000sq.km and per100, 000 adults in Ethiopia.

Source: Author's analysis based on data from 2005/2006 to December 31, 2015 NBE report and data from Banking Supervision Directorate of NBE.

\section{Conclusion and Recommendations}

\subsection{Conclusion}

This paper focused on three main objectives. The first goal is to analyze the access to financial services in 
Ethiopia. The Second goal is to measure the usage of financial services in Ethiopia. The third goal is to identify and address barriers to financial inclusion. The final goal is to analyze and document the significance of access to and usage of financial services in financial inclusion policy decision making.

Despite the fact that Ethiopia has achieved its rapid financial sector growth in the last couple of years, many households are still excluded from access to financial services in the jurisdiction. The analysis of the access and usage of financial services by individuals found that only 33.86 percent of adults have account with formal financial institutions. They use their account to keep money safe, send and receive payments, and to get credit services and foreign exchange services. The findings show that Ethiopia lags behind Sub-Saharan Africa and low income economies in this aspect. The main obstacles that contribute to this are lack of enough money, distance, cost and documentation requirements. The poor, youth, rural residents and women appear to face greater constraints for access to financial services in jurisdiction. The share of adults with mobile money account is only 0.028 percent, even though the mobile or internet access at home was 57 Percent. This shows there is a promising potential for mobile based financial inclusion. The finding shows that 22.37 percent of adults reported having saved formally, at financial institutions and 47.3 percent of adults reported having borrowed money in the past 12 months. Analysis of access to financial services by firms shows that 92 percent of firms have saving or checking account at financial institutions and 40 percent of firms reported getting credit as their main barriers. The firms with an outstanding loan or line of credit are 29.6 percent in $2015 / 16$. This shows that 70.4 percent of firms in Ethiopia tend to have no line of credit. It is very hard to access finance for starting and small firms.

Finally, the analysis of the access and usage of financial services by individuals identified physical, bureaucratic, and financial barriers. The physical barriers such as access to bank branches and ATMs; and bureaucratic barriers such as difficulty to get credits and saving products by poor, due to market failures such as constraints to access due to regulations and structure of financial institutions; and financial barriers such as minimum cost of opening a saving account and fixed transaction costs are important obstacles to use financial services in Ethiopia.

\subsection{Recommendations}

It is possible to lower obstacles of financial inclusion with regulating well the financial system, healthy competition and building better enabling environment.

Identifying the root causes and addressing it properly appears to be removing the distance, cost, credit and documentation barriers. However, market failures and behavioral problems tend to be addressed through designing of appropriate financial products. Removing challenges and expanding financial inclusion tend to be possible with the promise of new technologies. For instance, mobile payment, mobile banking and use of biometric devices can lessen cost, speed up transfers and increase household transaction security.

\section{References}

Aportela, F. (1999). Effects of Financial Access on Savings by Low-Income People. Banco de Mexico.

Ashraf, N., Karlan, D., \& Yin, W. (2010). Female Empowerment: Further Evidence from a Commitment Savings Product in the Philippines. World Development, 28(3), 333-44. https://doi.org/10.1016/j.worlddev.2009.05.010

Beck, T., Levine, R., \& Levkov, A. (2010). Big Bad Banks? The Winners and Losers from Bank Deregulation in the United States. Journal of Finance, 65(5), 1637-67. https://doi.org/10.1111/j.1540-6261.2010.01589.x

Cai, H., Chen, Y., Fang, H., \& Zhou, L. (2010). The Effect of Microinsurance on Economic Activities: Evidence from a Randomized Natural Field Experiment. Working paper, Department of Economics, University of Pennsylvania, Philadelphia, PA. https://doi.org/10.1162/REST_a_00476

Demirguc-Kunt, A., Klapper, L., Singer, D., \& Oudheusden, P. V. (2015). Measuring Financial Inclusion around the world: The Global Findex Database (2014). Policy Research Working Paper 7255, World Bank, Washington, DC. https://doi.org/10.1596/1813-9450-7255

Dupas, P., \& Robinson, J. (2009). Savings Constraints and Microenterprise Development: Evidence from a Field Experiment in Kenya. NBER Working Paper 14693. https://doi.org/10.3386/w14693

IMF (International Monetary Fund). (2013). Article IV Consultation: The Federal Democratic Republic of Ethiopia: Staff Report for the 2013 Article IV Consultation. IMF Country Report No. 13/308. Washington, DC: IMF. Retrieved from https://www.imf.org/external/pubs/ft/scr/2013/cr13308.pdf

IMF (International Monetary Fund). (2014). Article IV Consultation Staff Report; Press Release; and Statement by The Executive Director for The Federal Democratic Republic Of Ethiopia. IMF Country Report No. 14/303. Washington, DC: IMF. Retrieved from https://www.imf.org/external/pubs/ft/scr/2014/cr14303.pdf 
Karlan, D., \& Zinman, J. (2010). Expanding Credit Access: Using Randomized Supply Decisions to Estimate the Impacts. Review of Financial Studies, 23, 433-64. https://doi.org/10.1093/rfs/hhp092

National Bank of Ethiopia. (1999/00-2014/15). Financial sector Data: Banks, Microfinance institutions and insurance companies. Raw data on overall financial sector, National Bank, Addis Ababa, Ethiopia.

OECD. (2013). The role of financial education in financial inclusion: OECD/INFE Evidence. Policies and Illustrative Case Studies. Retrieved from https://www.microfinancegateway.org/sites/default/files/mfg-en-paper-the-role-of-financial-education-in-fin ancial-inclusion-oecdinfe-evidence-policies-and-illustrative-case-studies-jun-2013.pdf

World Bank. (2014a). Global Financial Development Report 2014: Financial Inclusion. Washington, DC: World Bank. Retrieved from http://hdl.handle.net/10986/16238

World Bank. (2014d). Global Financial Inclusion (Global Findex) Database. World Bank Group. Retrieved from http://datatopics.worldbank.org/financialinclusion/country/ethiopia

World Bank. (2015a). Enterprise Surveys (http://www.enterprisesurveys.org). The World Bank. Retrieved from http://www.enterprisesurveys.org/data/exploreeconomies/2015/ethiopia\#firm-characteristics

World Bank. (2015b). The Financial sector Database. The World Development Indicators, World Bank, Washington, DC. Retrieved from http://databank.worldbank.org/data/download/WDI_csv.zip

\section{Copyrights}

Copyright for this article is retained by the author(s), with first publication rights granted to the journal.

This is an open-access article distributed under the terms and conditions of the Creative Commons Attribution license (http://creativecommons.org/licenses/by/4.0/). 